\title{
Evaluation of Spring Maize Hybrids under Irrigated Conditions
}

\author{
Manpreet Jaidka*, Navjot Singh Brar and Manoj Sharma
}

\author{
PAU's Krishi Vigyan Kendra, Langroya, SBS Nagar (Punjab), India
}

*Corresponding author

\section{Keywords}

Spring maize, Grain: Cob ratio, 100-Seed weight,

Shelling percentage,

Grain yield

Article Info

Accepted:

17 July 2018

Available Online:

10 August 2018

\section{A B S T R A C T}

An investigation entitled "Evaluation of spring maize hybrids under irrigated conditions" was conducted at the instructional farm of Krishi Vigyan Kendra Langroya to check the yield potential of three maize hybrids during spring 2018 season. The experiment was laid out in randomized complete block design (RCBD) with six replications. All the crop management practices were followed as per the recommendations of Punjab Agricultural University, Ludhiana. The statistical analysis of data revealed that all the hybrids were non-significantly different with respect to maize cob weight, cob weight, grain: cob ratio, cob length, cob girth at base, middle and top. Numerically, P1844 resulted in highest value of maize cob weight, cob weight, grain: cob ratio, cob length, cob girth at base, middle and top in comparison to PMH 10 and DKC 9108. Maize hybrid P 1844 had significantly higher number of rows per cob (17.50) as compared to PMH 10 (14.67) but statistically at par with DKC 9108 (16.33). Other yield attributes viz., shelling percentage, 100-seed weight was found to be non-significantly different. The significantly higher grain yield was recorded in P 1844 hybrid (85.46 q/ha) followed by DKC 9108 (69.55 q/ha) and PMH 10 (68.71 q/ha).

\section{Introduction}

In Punjab, maize crop is cultivated on an area of 1.16 lakh ha with production and productivity of 4.45 lakh tonne and 38.35 $\mathrm{q} /$ ha, respectively whereas in SBS Nagar district, it was cultivated on an area of 7,700 ha with production and productivity of 33,000 MT and 42.39 q/ha, respectively (Anon, 2018). Various biotic and abiotic factors affect the realization of better grain yield directly or indirectly. To tackle with these factors, agronomic and breeding approaches play a pivotal role. Breeding approach relies upon the development of superior cultivars which can perform better relative to existing ones. Both public and private sectors have done consistent work in the development of maize hybrids viz., PMH 10 of Punjab Agricultural University, Ludhiana; DKC 9108 of Monsanto seeds and P 1844 of Du Pont Pioneer. The performance of a particular hybrid/cultivar varies from one area to another which can be attributed to variation in the soil characteristics, existing weather conditions; availability of irrigation facilities etc. Sharma et al., (2014) studied performance of different maize hybrids sown by the farmers in the Kapurthala district of Punjab and reported that the grain yield obtained varied between 70.0 
to 100.8 q/ha. Similarly, Manan et al., (2016) reported that the farmers were using fertilizers and pesticides without taking in to account recommendations made by different research institutes which has reduced the margin of profit day by day.

Keeping in view the above mentioned factors, an investigation was undertaken to evaluate the performance of three hybrids viz., $\mathrm{PMH}$ 10, DKC 9108 and $\mathrm{P} 1844$ under the irrigated conditions so that the farmers of the area can be guided properly.

\section{Materials and Methods}

The investigation was carried out at the instructional farm of Krishi Vigyan Kendra (KVK) Langroya. KVK Langroya is located in sub-tropical climatic regime with height of $247 \mathrm{~m}$ from mean sea level. The experiment was laid out in randomized complete block design (RCBD) with six replications. The gross and net plot size was $21.6 \mathrm{~m}^{2}$ and 4.8 $\mathrm{m}^{2}$, respectively. Pre-sowing irrigation was followed by preparation of fine seed bed with 3-4 ploughings. The sowing of crop was done during spring season on 20.02.2018 on the southern side of east-west direction ridges at $60 \times 20 \mathrm{~cm}$ spacing with a seed rate of $25 \mathrm{~kg} / \mathrm{ha}$ after seed treatment with Carbendazim @ $3 \mathrm{~g}$ and Gaucho @ $6 \mathrm{ml} / \mathrm{kg}$ seed, respectively. Fertilizers were applied as per recommendations by the Punjab Agricultural University, Ludhiana i.e., urea @ $75 \mathrm{~kg} / \mathrm{ha}$, DAP @ 137.5 kg/ha and MOP @ 50 kg/ha as basal dose followed by application of urea @ $75 \mathrm{~kg} / \mathrm{ha}$ each at knee height and tasseling stages. For the management of weeds, sowing of crop was followed by pre-emergence application of Atrazine @ 2kg/ha within $2 \mathrm{~d}$ of sowing using knapsack sprayer and flood jet nozzle and earthing-up of crop was done $25 \mathrm{~d}$ after sowing. For the control of Lepidopteron insects, Decis was sprayed @ $200 \mathrm{ml} / \mathrm{ha}$ at 20 days after sowing. Yield attributing factors like number of rows/cob, cob length, cob girth was calculated by randomly selecting the 10 cobs from each experimental plot. The data were represented as average value of these 10 cobs. The number of rows/cob, cob weight, dehusked cob weight, grain weight/cob was calculated as an average of randomly selecting the 5 maize cobs from each plot. Shelling percentage was calculated as follows:

Shelling percentage $=100-\{$ (cob weight-grain weight $) \times 100 /$ cob weight $\}$

Grain: Cob ratio was calculated as follows:

Grain: Cob ratio $=$ Grain weight per cob/Dehusked cob weight

Grain yield q/ha was calculated from grain yield of each experimental plot as follows:

Grain yield $(\mathrm{q} / \mathrm{ha})=$ Plot yield $\times 10000 /$ plot size

A correlation matrix of independent variables with grain yield as dependent variable was estimated. The various data were statistically analyzed by using OPSTAT software. All possible pairs of treatment means were compared using Duncan's multiple range test (DMRT) at 5 per cent probability level.

\section{Results and Discussion}

\section{Grain: Cob ratio}

The statistical analysis of data (Table 1) on maize cob weight showed that although $\mathrm{P}$ 1844 (268.93) surpassed the PMH 10 and DKC 9108 hybrids numerically by a percentage of 21.5 and 18.6, respectively yet the difference was non-significant. The minimum maize cob weight was recorded in PMH 10. A similar trend was recorded in cob weight (after shelling) of the hybrids in which all the treatments were at par with each other. Numerically, P 1844 had highest cob weight 
which was computed to be 16.9 and 14.4 per cent higher as compared to PMH 10 and DKC 9108, respectively. Furthermore, analysis of data on grain weight per cob also revealed a non-significant difference between all the hybrids.

Highest grain weight per cob was recorded in P1844 which was 22.6 and 19.6 per cent higher than PMH 10 and DKC 9108, respectively. Similarly, all the hybrids showed non-significant variation from each other with respect to grain: cob ratio, $\mathrm{P} 1844$ resulted in highest (4.27) grain: cob ratio in comparison to PMH 10 (4.11) and DKC 9108 (4.15).

\section{Cob length and cob girth}

The data (Table 2) pertaining to cob length revealed a non-significant difference between the treatments. $\mathrm{P} 1844$ hybrid recorded highest cob length as compared to PMH 10 and DKC 9108 with an increase of 0.4 and 10.3 per cent, respectively. Similarly, all the maize hybrids varied non-significantly from each with respect to cob girth at base, middle as well as at top. Highest cob girth was recorded in $\mathrm{P}$ 1844 in comparison to other two hybrids. For instance, in $\mathrm{P} 1844$, an increase in cob girth at the middle was computed to be 7.4 and 2.3 per cent as compared to PMH 10 and DKC 9108, respectively (Fig. 1 and 2).

Fig.1 Maize cobs of PMH 10, DKC 9108 and P 1844

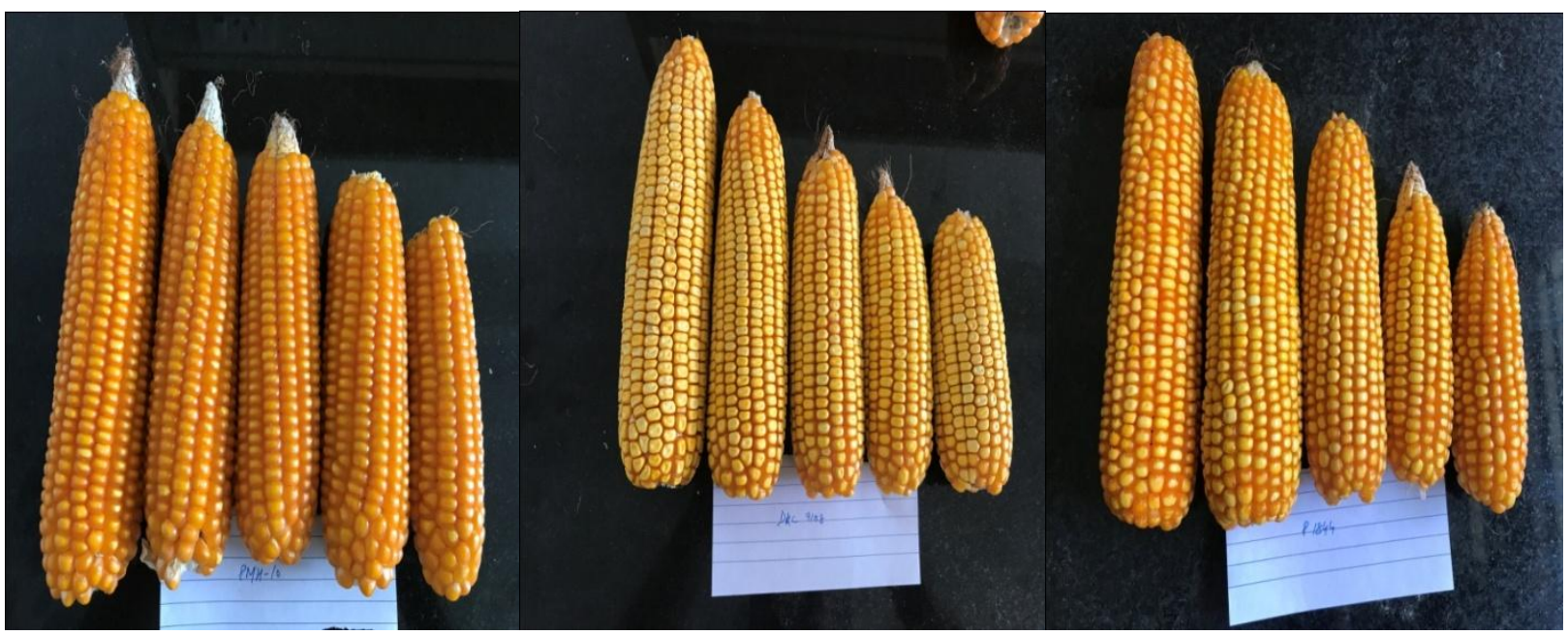

Fig.2 Cobs of maize hybrids PMH 10, DKC 9108 and P1844

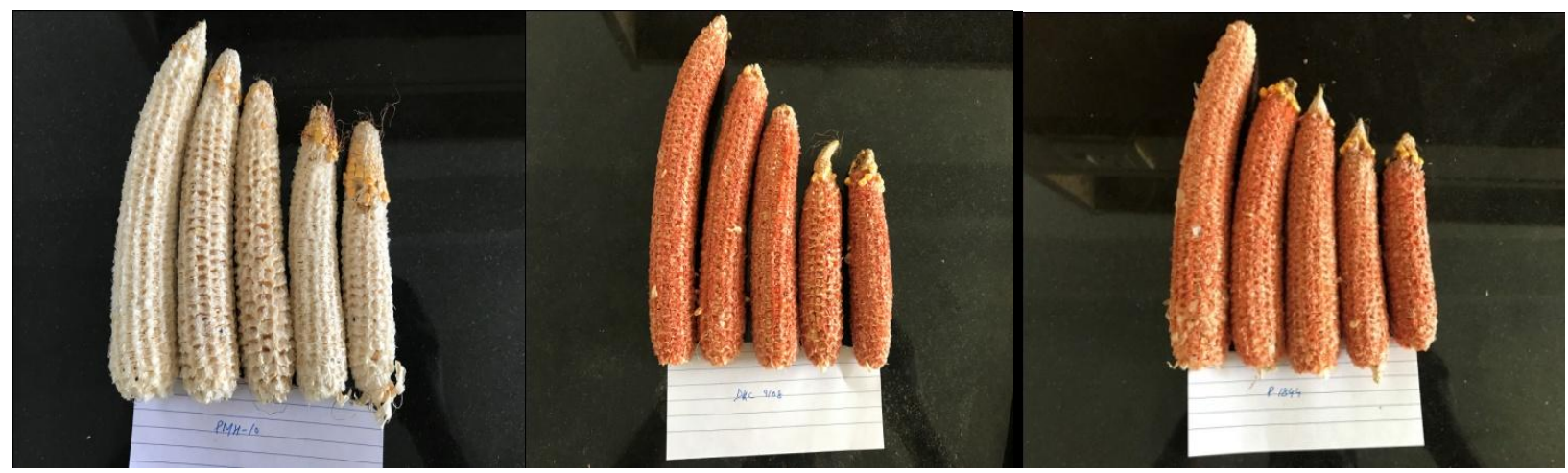


Int.J.Curr.Microbiol.App.Sci (2018) 7(8): 3212-3217

Table.1 Grain: Cob ratio of maize hybrids

\begin{tabular}{|l|l|c|c|c|c|}
\hline $\begin{array}{c}\text { Sr. } \\
\text { No. }\end{array}$ & Name of hybrid & $\begin{array}{c}\text { Maize Cob } \\
\text { weight }(\mathrm{g})\end{array}$ & $\begin{array}{c}\text { Cob weight }(\mathrm{g}) \\
\text { (after shelling) }\end{array}$ & $\begin{array}{c}\text { Grains weight /cob) } \\
(\mathrm{g})\end{array}$ & $\begin{array}{c}\text { Grain: Cob } \\
\text { ratio }\end{array}$ \\
\hline 1. & PMH 10 & $221.31^{\mathrm{ns}}$ & $43.34^{\mathrm{ns}}$ & $177.97^{\mathrm{ns}}$ & $4.11^{\mathrm{ns}}$ \\
\hline 2. & P 1844 & 268.93 & 50.68 & 218.26 & 4.27 \\
\hline 3. & DKC 9108 & 226.84 & 44.31 & 182.52 & 4.15 \\
\hline & SE (d) & 24.70 & 4.30 & 20.87 & 0.23 \\
\hline SE (m) & 17.47 & 3.04 & 14.76 & 0.16 \\
\hline CV & 17.9 & 16.15 & 18.74 & 9.64 \\
\hline
\end{tabular}

Table.2 Cob length and cob girth of maize hybrids

\begin{tabular}{|c|c|c|c|c|c|}
\hline Sr. No. & Name of hybrid & $\begin{array}{c}\text { Cob length } \\
(\mathbf{c m})\end{array}$ & $\begin{array}{c}\text { Cob girth at base } \\
(\mathbf{c m})\end{array}$ & $\begin{array}{c}\text { Cob girth at } \\
\text { middle }(\mathbf{c m})\end{array}$ & $\begin{array}{c}\text { Cob girth at } \\
\text { top (cm) }\end{array}$ \\
\hline 1. & PMH 10 & $17.89^{\mathrm{ns}}$ & $15.21^{\mathrm{ns}}$ & $14.89^{\mathrm{ns}}$ & $12.72^{\mathrm{ns}}$ \\
\hline 2. & P 1844 & 17.96 & 15.96 & 15.99 & 13.52 \\
\hline 3. & DKC 9108 & 16.28 & 15.47 & 15.63 & 12.75 \\
\hline & SE (d) & 0.84 & 0.62 & 0.34 & 0.19 \\
\hline & SE (m) & 0.60 & 0.44 & 0.24 & 0.14 \\
\hline
\end{tabular}

Table.3 Grain yield and yield attributes of maize hybrids

\begin{tabular}{|l|c|c|c|c|c|c|}
\hline Sr. No. & $\begin{array}{c}\text { Name of } \\
\text { hybrid }\end{array}$ & $\begin{array}{c}\text { Rows/co } \\
\text { b (Nos.) }\end{array}$ & $\begin{array}{c}\text { Grains/cob } \\
\text { (Nos.) }\end{array}$ & $\begin{array}{c}\text { Shelling } \\
\text { percentage }\end{array}$ & $\begin{array}{c}100 \text { seed weight } \\
(\mathrm{g})\end{array}$ & $\begin{array}{c}\text { Grain } \\
\text { yield } \\
\text { (g/ha) }\end{array}$ \\
\hline 1. & PMH 10 & $14.67^{\mathrm{c}}$ & $411.80^{\mathrm{ns}}$ & $80.41^{\mathrm{ns}}$ & $32.28^{\mathrm{ns}}$ & $68.71^{\mathrm{c}}$ \\
\hline 2. & P 1844 & $17.50^{\mathrm{a}}$ & 554.33 & 81.17 & 33.63 & $85.46^{\mathrm{a}}$ \\
\hline 3. & DKC 9108 & $16.33^{\mathrm{ab}}$ & 528.17 & 80.75 & 33.97 & $69.55^{\mathrm{b}}$ \\
\hline & SE (d) & 0.71 & 70.06 & 6.07 & 2.42 & 0.43 \\
\hline & SE (m) & 0.50 & 49.54 & 4.29 & 1.71 & 0.30 \\
\hline & CV & 7.58 & 24.36 & 13.01 & 12.58 & 0.99 \\
\hline
\end{tabular}


Table.4 Correlation matrix of independent variables with grain yield as dependent variable

\begin{tabular}{|c|c|c|c|c|c|c|c|c|c|c|c|c|c|}
\hline Variable & MCW & CW & GWPC & $\mathrm{G}: \mathrm{C}$ & CL & CGB & CGM & CGT & $\mathbf{R C}$ & GC & SP & SW & GY \\
\hline MCW & & & & & & & & & & & & & \\
\hline $\mathbf{C W}$ & $1.00 *$ & & & & & & & & & & & & \\
\hline GWPC & $1.00 * *$ & $1.00 *$ & & & & & & & & & & & \\
\hline $\mathbf{G}: \mathbf{C}$ & $0.99^{\mathrm{NS}}$ & $0.99^{\mathrm{NS}}$ & $0.99^{\mathrm{NS}}$ & & & & & & & & & & \\
\hline $\mathrm{CL}$ & $0.44^{\mathrm{NS}}$ & $0.43^{\mathrm{NS}}$ & $0.44^{\mathrm{NS}}$ & $0.31^{\mathrm{NS}}$ & & & & & & & & & \\
\hline CGB & $0.97^{\mathrm{NS}}$ & $0.97^{\mathrm{NS}}$ & $0.97^{\mathrm{NS}}$ & $0.99^{\mathrm{NS}}$ & $0.21^{\mathrm{NS}}$ & & & & & & & & \\
\hline CGM & $0.82^{\mathrm{NS}}$ & $0.83^{\mathrm{NS}}$ & $0.82^{\mathrm{NS}}$ & $0.89^{\mathrm{NS}}$ & $-0.16^{\mathrm{NS}}$ & $0.93^{\mathrm{NS}}$ & & & & & & & \\
\hline CGT & $0.99 *$ & $0.99^{\mathrm{NS}}$ & $0.99 *$ & $0.98^{\mathrm{NS}}$ & $0.50^{\mathrm{NS}}$ & $0.95^{\mathrm{NS}}$ & $0.77^{\mathrm{NS}}$ & & & & & & \\
\hline $\mathbf{R C}$ & $0.87^{\mathrm{NS}}$ & $0.88^{\mathrm{NS}}$ & $0.87^{\mathrm{NS}}$ & $0.93^{\mathrm{NS}}$ & $-0.06^{\mathrm{NS}}$ & $0.96^{\mathrm{NS}}$ & $0.99^{\mathrm{NS}}$ & $0.83^{\mathrm{NS}}$ & & & & & \\
\hline GC & $0.72^{\mathrm{NS}}$ & $0.73^{\mathrm{NS}}$ & $0.72^{\mathrm{NS}}$ & $0.81^{\mathrm{NS}}$ & $-0.31^{\mathrm{NS}}$ & $0.87^{\mathrm{NS}}$ & $0.99^{\mathrm{NS}}$ & $0.67^{\mathrm{NS}}$ & $0.97^{\mathrm{NS}}$ & & & & \\
\hline SP & $0.94^{\mathrm{NS}}$ & $0.94^{\mathrm{NS}}$ & $0.93^{\mathrm{NS}}$ & $0.97^{\mathrm{NS}}$ & $0.10^{\mathrm{NS}}$ & $0.99^{\mathrm{NS}}$ & $0.97^{\mathrm{NS}}$ & $0.91^{\mathrm{NS}}$ & $0.98^{\mathrm{NS}}$ & $0.91^{\mathrm{NS}}$ & & & \\
\hline SW & $0.43^{\mathrm{NS}}$ & $0.44^{\mathrm{NS}}$ & $0.42^{\mathrm{NS}}$ & $0.54^{\mathrm{NS}}$ & $-0.63^{\mathrm{NS}}$ & $0.63^{\mathrm{NS}}$ & $0.87^{\mathrm{NS}}$ & $0.36^{\mathrm{NS}}$ & $0.82^{\mathrm{NS}}$ & $0.93^{\mathrm{NS}}$ & $0.71^{\mathrm{NS}}$ & & \\
\hline$\overline{G Y}$ & $1.00 *$ & $0.99 *$ & $0.99 *$ & $0.98^{\mathrm{NS}}$ & $0.49^{\mathrm{NS}}$ & $0.95^{\mathrm{NS}}$ & $0.78^{\mathrm{NS}}$ & $1.00 *$ & $0.84^{\mathrm{NS}}$ & $0.67^{\mathrm{NS}}$ & $0.91^{\mathrm{NS}}$ & $0.37^{\mathrm{NS}}$ & \\
\hline
\end{tabular}

MCW-maize cob weight; CW-cob weight; GWPC-grain weight per cob; G:C-grain:cob;CL- cob length; CGB-cob girth at base; CGM- cob girth at middle; CGTcob girth at top; RC-rows per cob; GC-grains per cob; SP-shelling percentage; SW-100 seed weight; GY-grain yield 


\section{Yield and yield attributes}

The data (Table 3) of number of rows per cob showed a significant increase in P 1844 hybrid as compared to PMH 10 but at par with DKC 9108. Increase in number of rows per cob in $\mathrm{P} 1844$ (17.5) was worked out to be 19.3 and 7.2 as compared to PMH 10 and DKC 9108, respectively but the differences were a non-significant. Although the value in maize hybrid P 1844 was at par with other two hybrids but numerically an increasing trend was recorded with per cent increase of 34.6 and 4.95 as compared to PMH 10 and DKC 9108, respectively. Similarly, a nonsignificant difference was observed between the maize hybrids with respect to shelling percentage. The highest shelling percentage was recorded in $\mathrm{P}$ 1844 (81.17) as compared to PMH 10 (80.41) and DKC 9108 (80.75) with per cent increase of 0.95 and 0.52 , respectively. Furthermore, data on 100seed weight revealed a non-significant difference between the hybrids. Numerically, highest 100seed weight was observed in DKC 9108 with per cent increase of 5.24 and 1.01 as compared to maize hybrids PMH 10 and P 1844, respectively. The data on grain yield of hybrids showed a significantly higher grain yield of 1844 as compared to PMH 10 and DKC 9108 with per cent increase of 24.4 and 22.9, respectively. Highest grain yield in P 1844 can be attributed to increase in number of grains per cob (Table 3), grain weight per cob (Table 1), number of rows per cob (Table 3) in comparison to PMH 10 and DKC 9108.

\section{Correlation analysis}

The correlation analysis (Table 4) of all the parameters with grain yield revealed a significant and highly positive correlation of maize cob weight, cob weight, grain weight per cob and cob girth at top with grain yield of hybrids. At the same time, a highly significant positive correlation (1.00) was recorded between maize cob weight and grain weight per cob. A negative but non-significant correlation of cob length with cob girth at mid, cob length, grains per cob and 100 -seed weight was also recorded.

From the study, it can be concluded that maize hybrid P 1844 proved superior to PMH 10 and DKC 9108 in terms of number of rows per cob and grain yield.

Although, P1844 was found at par with other hybrids with respect to maize cob weight, cob weight, grain: cob ratio, cob length, cob girth at base, middle and top, shelling percentage, number of grains per cob but numerically it surpassed both hybrids whose benefit is clearly indicated by significant enhancement in grain yield.

The correlation analysis of all the parameters with grain yield revealed a significant and highly positive correlation of maize cob weight, cob weight, grain weight per cob and cob girth at top with grain yield of hybrids.

\section{References}

Anonymous (2018) Package of Practices for Kharif Crops of Punjab. Punjab Agricultural University, Ludhiana.

Manan Jatinder, Sharma Manoj, Singh Gurmeet and Singh Gobinder (2016). Efect of application of various inputs by the farmers and the yield of spring maize hybrids. $J$ Krishi Vigyan 4(2): 22-27

Sharma Manoj, Singh Onkar, Singh Gobinder and Kaur Gurpreet (2014). A snap shot of spring maize cultivation in Kapurthala and Jalandhar districts under central plain zone of Punjab. J Krishi Vigyan 3(1): 1-4.

\section{How to cite this article:}

Manpreet Jaidka, Navjot Singh Brar and Manoj Sharma. 2018. Evaluation of Spring Maize Hybrids under Irrigated Conditions. Int.J.Curr.Microbiol.App.Sci. 7(08): 3212-3217. doi: https://doi.org/10.20546/ijcmas.2018.708.344 